This article is distributed under the terms of the Creative Commons Attribution 3.0 PL (c) Copyright by Uniwersytet Warszawski Katedra Studiów Interkulturowych Europy Środkowo-Wschodniej \& individual articles to their Authors

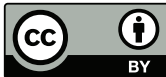

doi: 10.32612/uw.2543618X.2020.pp.169-192

Przegląd Środkowo-Wschodni, 5, 2020

ISSN 2543-618X elSSN 2545-1324

Nr art. 20200505

Data przesłania: 03.02.2019

Data akceptacji: 09.09.2019

Виктор Острога

Кафедра таможенного дела Факультета международных отношений Белорусского государственного университета

ostroga.v@mail.ru

ORCID: 0000-0003-0599-465X

\title{
Белорусские таможенники в борьбе с контрабандой историко-культурных ценностей (1944-1991 гг.)
}

\section{Celnicy białoruscy w walce z przemytem zabytków historycznych i kulturalnych w latach 1944-1991}

Artykuł jest poświęcony działalności służby celnej na terytorium Białorusi Radzieckiej w latach 1944-1991. Autor analizuje działalność celników mającą na celu zapobieganie przemytowi zabytków historii i kultury. Analizie poddano metody i możliwości działania funkcjonariuszy celnych w dziedzinie ochrony dziedzictwa kulturowego. Szczególną uwagą opatrzono przeciwdziałanie przemytowi przez granicę przedmiotów religijnych, głównie ikon. Zanalizy wynika, że na początku lat 70. XX w. miał miejsce masowy przemyt ikon, które po zatrzymaniu przez celników były najczęściej niszczone. W następnych latach pochodzące z przemytu ikony trafiały już do muzeów na Białorusi. W ten sposób w Brześciu powstało unikatowe muzeum ikon pochodzących z przemytu. W artykule zostały przedstawione najbardziej ciekawe i charakterystyczne sposoby i miejsca ukrywania przez przemytników historycznych i kulturowych artefaktów. Autor doszedł do wniosku, że w omawianym okresie celnicy białoruscy skutecznie przeciwdziałali nielegalnemu wywozowi z kraju zabytków historycznych i kulturowych.

Słowa kluczowe: Białoruś, zabytki kultury i historii, przedmioty religijne, ikony, ustawodawstwo, cło, celnik, przemyt, przemytnik, kryjówka. 
Проблема противодействия незаконному вывозу через государственные границы историко-культурных ценностей, как неотъемлемой части национального и мирового культурного наследия человечества существовала давно. Если исходить из современных представлений и стандартов в области обеспечения охраны этих артефактов, обозначенная проблема актуальна не менее ста лет. В новейшей истории Беларуси борьба с контрабандой идет фактически перманентно, то выходя на свой пик, то несколько затихая. Одним из ее ярких и характерных периодов в истории противодействия вывозу культурного достояния были послевоенные десятилетия Советской Беларуси. Динамика работы белорусских таможенников того времени демонстрирует рост напряжения усилий стражей экономических рубежей в противодействии алчным и хитроумным контрабандистам, стремившимся переправить через границу побольше исторических и культурных раритетов.

Несмотря на существование постоянного общественного интереса к этой проблеме, ее несомненную актуальность, тема борьбы с контрабандой историко-культурных ценностей достаточно редко оказывалась в поле зрения исследователей, зачастую по причине закрытости ее источниковой и документарной базы. Поэтому уровень научной разработанности на сегодняшний день далек от необходимого. Среди наиболее интересных современных белорусских исследований можно отметить работы гродненского краеведа В.Ю. Саяпина и научно-популярное издание «На страже культурного наследия. Таможенная служба Беларуси в борьбе с контрабандой культурных ценностей», подготовленное группой сотрудников Государственного таможенного комитета Республики Беларусь ${ }^{1}$.

С момента своего появления Советская власть пыталась препятствовать нелегальному вывозу историко-культурных ценностей. Конечно же, имелись особенности в самом понимании исто-

${ }^{1}$ Саяпин В.Ю., Таможенная служба. В 2 кн. Кн. 2. Борьба с контрабандой, Гродно 2005. 
рико-культурного раритета. К примеру, это касается предметов религиозного культа, в частности, икон. Новая власть, активно пропагандировавшая атеизм, не относила их к категории культурных ценностей, хотя сама интенсивно продавала эти предметы за рубеж. Вместе с тем, в начале 1920-х гг. уже в Советской Беларуси происходили периодические задержания контрабандных артефактов, которые позже, попадая в музейные фонды, становились объектами изучения исследователей-искусствоведов. Многие из этих раритетов находились в особом фонде Могилевского музея, своего рода первой белорусской коллекции «спасенных ценностей». Так, на специализированной выставке, посвящённой уникальным произведениям белорусских мануфактур XVIII-XIX вв. - слуцким поясам, проходившей в Минске в апреле 1927 г., как раз были представлены эти знаменитые элементы одежды шляхты, задержанные сотрудниками Минской таможни ${ }^{2}$. Но в довоенный период, как в 1920-х, так и в 1930-х гг., основная масса контрабандистов не стремилась провезти историко-культурные ценности. Этим промыслом изредка занимались в основном иностранные граждане, приезжавшие по делам в СССР.

После окончания Второй мировой войны контрабанда культурных ценностей стала несравнимо более масштабной. Именно в послевоенный период сложилась разветвленная сеть хорошо организованных преступных групп, специализировавшихся на краже, контрабанде и сбыте произведений искусства. Времена контрабандиста-одиночки стали проходить.

Уже в конце 1940-х гг. в связи с тем, что пришло повсеместное понимание того, что ущерб, причиняемый преступлениями, связанными с культурными ценностями, наносился не только отдельным странам и народам, но и мировой культуре в целом, наиболее передовые государства начали активно вырабатывать международно-

${ }^{2}$ Альбом-каталог «Слуцкие пояса». http://nasledie-sluck.by/ru/sluchina/114/4919/. Дата доступа 15.12.2018. 
правовые меры по их охране. Так, в рамках ООН была создана специальная Организация Объединенных Наций по вопросам образования, науки и культуры (ЮНЕСКО), под эгидой которой государства взяли на себя обязательства по защите памятников культуры. В 1954 г. по инициативе ЮНЕСКО была принята Гаагская конвенция о защите культурных ценностей в случае вооруженного конфликта. В 1964 г. на проходившей в Париже XII сессии Генеральной конференции ЮНЕСКО была принята Рекомендация о меpax, направленных на запрещение и предупреждение незаконного вывоза, ввоза и передачи права собственности на культурные ценности. В разделе «Общие принципы» этой Рекомендации, в частности, указывалось: «Каждое государство-член должно принять необходимые меры, чтобы предупредить незаконную передачу права собственности на культурные ценности» ${ }^{3}$. В 1970 г. была принята Конвенция о мерах, направленных на запрещение и предупреждение незаконного ввоза, вывоза и передачи права собственности на культурные ценности, а в 1972 г. - Конвенция об охране всемирного культурного и природного наследия.

Однако, несмотря на активные и разноплановые действия международных организаций и национальных правительств, контрабанда культурных и исторических ценностей ликвидирована не была, а ее масштабы не уменьшались. Опасность утраты части культурного наследия стала темой обсуждения в прессе и специальной литературе различных стран мира.

В СССР, и в Советской Беларуси, в частности, в первые послевоенные годы контрабанда была в большей степени ввозной и характеризовалась задержанием, в первую очередь, дефицитных потребительских товаров (табак, спички, питьевая сода, наручные часы, драгоценности, красители для тканей, ткани, кожа, галанте-

\footnotetext{
${ }^{3}$ На страже культурного наследия: Таможенная служба Беларуси в борьбе с контрабандой культурных цеенностей, ред.: А.Ф. Шпилевский, Минск 2007, c. 18
} 
рея и др.). В итоге 85\% контрабанды задерживалось при вывозе из страны, а 15\% при ввозе. Правительство СССР, исходя из понимания политических и экономических приоритетов того времени, принимало жесткие меры по контролю за ввозом и вывозом товаров через таможенную границу. Белорусские таможенники, действуя в соответствии с директивными указаниями, проводили тотальную проверку перемещаемых товаров, в том числе ручной клади и самих лиц, пересекающих границу. Советские власти требовали, чтобы таможенники и пограничники «решительно и настойчиво пресекали малейшие попытки провоза через государственную границу запрещенных предметов, материалов, валюты и валютных ценностей» ${ }^{4}$.

К примеру, 19 февраля 1953 г. сотрудниками отдела по борьбе с контрабандой Брестской таможни у советских немцев из Казахстана, переселявшихся на постоянное место жительства в Германию, было изъято 30 икон - 5 деревянных и 25 металлических. В июне 1953 г. начальник этого отдела Кутуков от имени таможни передал часть этих икон в дар Брестскому областному краеведческому музею. Это была самая первая после войны передача икон белорусским музеям. Одна из них - «Чудо св. Георгия о змие» и ныне хранится в фондах Брестского областного краеведческого музея ${ }^{5}$.

Тут, несколько забегая вперед, стоит отметить определенный парадокс. На то время это был редчайший случай, когда официальные представители атеистического государства передали в музей задержанные предметы религиозного культа. Удивительно, но факт, что лишь в начале 1970-х гг. иконы и другие религиозные реликвии в СССР были признаны историко-культурной ценностью и начали в обязательном порядке направляться таможнями в музеи. До

${ }^{4}$ На страже грании Отечества. История пограничной службы. Краткий очерк, Москва 1998, с. 417.

${ }^{5}$ На страже культурного наследия: Таможенная служба Беларуси в борьбе с контрабандой культурных цеенностей, ред.: А.Ф. Шпилевский, Минск 2007, c. 19 
этого они, даже писанные до XVI в., изымались и как предметы культа, «не представляющие художественной и исторической ценности» направлялись на ... сжигание (!?). Таким образом, советские таможенники «спасали» эти раритеты от вывоза за границу, а затем сами направляли уникальные произведения отечественной и мировой культуры на уничтожение. Лишь с начала 1970-х гг. их действия стали реальным спасением национального и мирового достояния от нелегального вывоза за рубеж. Так, в 1973 г. Брестский областной краеведческий музей, по согласованию с руководством местной таможни, получил в свои фонды первые произведения православной иконописи, а в 1976 г. на базе сформированной «золотой кладовой» была открыта временная выставка спасенных от контрабандистов икон. В 1973 г. также состоялась первая передача икон сотрудниками Гродненской таможни в Гродненский историко-археологический музей, что в последующем стало основой для формирования в нем крупной «таможенной» коллекции «Спасенных культурных ценностей» ${ }^{6}$.

Со второй половины $1950-$ х гг. в СССР, в условиях некоторой либерализации внутриполитической обстановки, активизировались международные торговые и культурные контакты. Стали открываться новые транспортные маршруты для все возрастающих товаро- и пасажиропотоков. Происходили серьезные изменения в организации таможенного контроля. Был отменен сплошной таможенный контроль, включая личный. Также была ликвидирована мелочная регламентация провоза личного имущества.

Несомненно, рубежным этапом развития таможенного контроля в СССР в сторону его либерализации стало инициированное советским руководством событие мирового масштаба - VI Всемирный фестиваль молодёжи и студентов, проходивший в июле-августе 1957 г. в Москве. В столицу СССР съехались 34000 человек

6 Государственная таможенная служба Республики Беларусь. История и современность, ред.: А.Ф. Шпилевский, Минск 2006, с. 226. 
из 131 страны мира. Для граждан до недавнего времени жестко закрытого от контактов с иностранцами совестного общества это было не просто уникальное событие, это стало даже неким культурным шоком. Подготовилась к этому событию и таможенная служба. В первую очередь, это касалось западных советских таможен, находившихся в БССР. Ведь основной поток участников фестиваля следовал по железной дороге. Так отдел Брестской таможни на пассажирском железнодорожном вокзале получил новый просторный таможенный зал со смонтированным в центре овальным досмотровым столом. Кроме того, таможня увеличила свой штат молодыми сотрудниками со знанием различных иностранных языков. Остальные таможенники стали усиленно изучать иностранные языки на специально организованных таможней курсах. Перед сотрудниками таможни в Бресте была поставлена ответственная задача быстро и качественно обеспечить таможенное оформление и контроль участников фестиваля, демонстрируя при этом гостеприимство и доброжелательность. С поставленными задачами они с честью справились. Фестиваль приоткрыл «железный занавес», окружавший СССР, и «интуристы» все чаще стали появляться в его крупных городах. Некоторые из иностранных граждан нелегально ввозили дефицитные товары, которые распространялись с помощью так называемых «фарцовщиков». Обратно за рубеж уже проторенными каналами незаконно вывозились различные товары из СССР, в том числе и историко-культурные артефакты. В итоге в 1950-е гг. с ростом пассажиропотока начала набирать обороты и вывозная из Советского Союза контрабанда. Так, за десять лет, с 1954 г. по 1964 г. объемы задержанной контрабанды выросли почти в 10 раз ${ }^{7}$.

В 1958 г. в целях обобщения практики выявления мест сокрытия контрабанды и выработки более совершенных способов про-

${ }^{7}$ На страже границ Отечества. История пограничной службы. Краткий очерк, Москва 1998, с. 487. 
тиводействия контрабандному провозу товаров через таможенную границу Советского Союза Главное таможенное управление Министерства внешней торговли СССР организовало в Москве закрытую выставку «Наиболее характерные способы сокрытия предметов контрабанды» ${ }^{8}$. Посетители выставки смогли увидеть самые изощрённые и хитроумные попытки разоблаченных контрабандистов переместить через советскую границу различных дефицитных и ценных товаров. Так, при вывозе из страны задержаны: наручные часы, фотоаппараты, будильники, радиолампы, фотопленка, изделия из меха, победитовые пластинки и др. При ввозе: ткани, головные платки, дамское белье, ювелирные изделия, валюта и др. На выставке не экспонировались культурные ценности. На то время их контрабанда только набирала обороты.

Несколько примеров с этой выставки. Так, в учебнике «Русская литература» в специально вырезанных гнездах вывозились наручные часы. В другом случае наручные часы были обнаружены в банке рыбных консервов «Салака». В узле мужского галстука контрабандистом были зашиты доллары США. Золотые цепочки и кольца пытались спрятать в нескольких грецких орехах. Победитовые пластинки преступник хотел провезти в печеньях домашнего изготовления.

С 1960-х гг., когда значительно возрос поток пассажиров и грузов, следующих через белорусский участок западной границы СССР, увеличилось количество и объемы задержаний историко-культурных ценностей. Нарушителями правил перемещения через таможенную границу культурных ценностей, как и прежде, были иностранцы, работники дипломатических миссий, различных зарубежных торговых фирм, члены их семей, туристы и, в меньшей степени, советские граждане. Так, 29 января 1973 г. сотрудником Гродненской таможни Ю.К. Киктенко в пассажирском вагоне поезда Ленинград - Варшава были обнаружены 8 икон, 6 из

\footnotetext{
${ }^{8}$ Острога В.А., Картинки с выставки, “Таможня и ВЭД” 2004, № 4, с. 63-64.
} 
которых находились в межпотолочном пространстве вагона, а 2 за котлом отопительной системы того же вагона9.

Выбирая наиболее ценное, контрабандисты стремились вывезти из СССР в первую очередь иконы. Именно они превалируют в протоколах задержаний контрабанды Брестской, Гродненской и Минской таможен с начала 1970-х гг. Заметим, что в то время таможенникам наиболее часто попадались работы мастеров иконописи русского Севера XVIII-XIX вв. В другом случае, в 19731974 гг. сотрудники Брестской таможни предотвратили вывоз редких перламутровых икон, созданных в иконописных мастерских Палестины.

Большую помощь в деле обнаружения контрабанды таможенникам всегда оказывали пограничники, работавшие в пунктах пропуска, как говорят «плечом к плечу». Так, в марте 1973 г. в Бресте при осуществлении пограничного и таможенного контроля у гражданина, выезжавшего из СССР на постоянное место жительство за рубеж, в багаже были обнаружены картины, похищенные из Государственного Эрмитажа в Ленинграде еще в 1940-е гг. Преступник пытался убедить стражей границы, что это просто дешевые копии, но вызванные эксперты различили на них штампы и инвентарные номера Эрмитажа. Раритеты вернули в родной музей ${ }^{10}$.

Особый интерес для таможенников представляли студенты из развивающихся стран, обучавшиеся в СССР. С начала 1960-х гг. их число стало быстро расти, и к 1990-му г. их число превысило 100 тысяч человек. Наиболее деятельные и беспринципные из этих студентов устанавливали связи с агентством «Интурист», советскими гражданами, пытались подкупить таможенников и «зарабатывали» тысячи и десятки тысяч рублей. Чаще всего подобные

${ }^{9}$ На страже культурного наследия: Таможенная служба Беларуси в борьбе с контрабандой культурных иеенностей, ред.: А.Ф. Шпилевский, Минск 2007, c. 21.

${ }^{10}$ История пограничной службы Беларуси / В.В. Давыдик [и др.], ред.: В.Г. Моисеенко, Минск 2011, с. 357. 
субъекты интересовались историческими раритетами, золотыми царскими монетами и иконами. Так, 30 января 1974 г. сотрудником Гродненской таможни И.И. Почобут была пресечена попытка студента Ленинградского института связи гражданина Гвинеи вывезти из СССР пассажирским поездом Ленинград - Берлин историко-культурные ценности. Одна икона была зашита предприимчивым африканцем между верхом и подкладкой его дорожной сумки, другая икона в окладе, а также бронзовый крест с эмалью и юбилейная медаль с изображением императрицы Елизаветы находились в кармане пиджака, надетого на пассажире ${ }^{11}$. Обращает внимание то, что «интерес» подобных студентов и других граждан зарубежных стран к старине был настолько велик, что, по некоторым данным, во второй половине 1980-х гг. таможенники задержали не одну тысячу контрабандных икон, некоторые из них были датированы XVI в. К слову, задержания проходили не только на границе. Так, в 1977 г. сотрудниками внутренней Минской таможни впервые были переданы три задержанные иконы в Музей Древнебелорусского искусства Института искусствоведения Академии наук БССР ${ }^{12}$.

Иногда таможенники становились свидетелями ужасного зрелища. Если иконы не вмещались в сумки, то контрабандисты их по-варварски, без сожаленья могли распилить их на две, четыре, а то и шесть частей, не жалея святых ликов и крестов. Так, одна из икон - «Спас в силах» - редчайший экземпляр, написанный в XVI в., была распилена преступником на две части для более скрытного перемещения через таможенную границу.

К сожалению, в отдельных случаях таможенники Беларуси были не в силах противостоять контрабандистам. Наиболее ловкие

${ }^{11}$ Саяпин В.Ю., Таможенная служба. В 2 кн. Кн. 2. Борьба с контрабандой, Гродно 2005, с. 257.

${ }^{12}$ На страже культурного наследия: Таможенная служба Беларуси в борьбе с контрабандой культурных цеенностей, ред.: А.Ф. Шпилевский, Минск 2007, c. 24. 
из них, раздобыв разрешительную бумагу с печатью, без особого затруднения могли вывезти за рубеж десяток шедевров иконописания. Так, в 1989 г. в центральном советском молодежном журнале «Смена» журналист А. Николаев в статье «Христопродавцы» описал подобный случай, произошедший в 1974 г. в пограничном Бресте. Как он пишет: в купе вагона прямого поезда Москва-Париж заходит таможенник. При виде большой иконы ослепительной красоты, он, не приглашая эксперта-искусствоведа, требует предъявления разрешительных документов. В ответ слышит: «Позвоните в Москву», и через несколько минут шедевр древнерусской иконописи XIV века из церкви в Печенеге «Святой Георгий» продолжает путь в Париж ${ }^{13}$. Сегодня, этот раритет, вероятно, украшает личную коллекцию богатого французского коллекционера, а мог бы давно стать жемчужиной любого белорусского музея.

К слову, в свое время за рубежом даже были изданы каталоги «русского искусства», которые, по мнению современных белорусских экспертов, в основной массе отображают предметы религиозного культа православия, преимущественно, иконы, которые удалось вывезти контрабандистам из СССР в 1970-х -1980-х гг.

В конце 1970-х гг. в Советском Союзе, в том числе и в БССР, был принят ряд новых дополнительных законодательных мер по усилению охраны памятников истории и культуры. Так, Постановление Совета Министров СССР от 12 ноября 1979 г. «О мерах по предотвращению незаконного вывоза культурных ценностей за пределы СССР» было направлено на недопущение незаконного вывоза за пределы государства произведений искусства и предметов старины, представляющих значительную художественную, историческую или культурную ценность. Министерство культуры СССР начало оказывать помощь таможням экспертами-искусствоведами. В частности, согласно постановлению, при Брестском областном управлении культуры была создана группа искусство-

\footnotetext{
${ }^{13}$ Николаев А. Христопродавцы // Смена. - 1989. - № 21, с. 7.
} 
ведов-контролеров, которая начала работать в тесном контакте с таможней. Стоит отметить, что в противодействии контрабанде исторических раритетов, конечно же, с учетом своих специфических задач, активно участвовали и оперативные подразделения Комитета государственной безопасности СССР. Так, в 1985 г. сотрудники Брестской таможни совместно с сотрудниками КГБ обнаружили и перекрыли канал, по которому из страны вывозились иконы, благодаря чему была пресечена деятельность преступной группы контрабандистов и их пособников. Конфискованные при этом иконы были переданы Брестскому областному краеведческому музею.

Отметим, что на масштабы контрабанды культурных ценностей значительное влияние оказывали различные международные события. Так, своеобразным вызовом для таможенников стала московская Олимпиада 1980 г., когда через границы СССР проехало более двухсот тысяч спортсменов и туристов. Таможенный контроль проводили все существовавшие на то время таможни БССР: Брестская, Гродненская и Минская. В это время таможни впервые получили рентгеновское сканирующее оборудование, что значительно ускоряло досмотр ручной клади. Резко вырос численный состав таможенных учреждений. В результате в период с 20 июня по 10 августа 1980 г. при использовании всех видов таможенного контроля только в одной Гродненской таможне было заведено 355 дел о контрабанде ${ }^{14}$.

В последнее десятилетие существования СССР таможенники также предотвратили вывоз большого количества исторических и культурных ценностей.

Совершенно уникальным случаем является задержание брестскими таможенниками в 1987 г. так называемого «афганского

${ }^{14}$ Олимпиада начинается ... с с таможни http://museum.customs.ru/index. php view $=$ article $\&$ catid $=7 \% 3$ Apublications \& id = 49\%3 A2014-01-20-06-3206\&format=pdf\&option=com_content\&Itemid=11. Дата доступа 15 01.2019. 
транзита» ${ }^{15}$. В феврале этого года, несмотря на наличие сопроводительных документов и всех пломб, внимание сотрудников дежурной смены Брестской таможни привлекло два грузовых контейнера международных перевозок. Два тяжелых металлических контейнера, общим весом более трех тонн, пришли в пограничный белорусский город из афганского Кабула. Адрес назначения - Гамбург, Западная Германия. В сопроводительных документах значилось, что в контейнерах следуют «восточные ковры».

Вскрыв первый контейнер, таможенники действительно увидели там аккуратно упакованные ковры. Во втором контейнере также были тюки с коврами. Однако, как оказалось при более тщательном досмотре, за коврами были спрятаны большие деревянные ящики. Ящики вскрыли, и взору таможенников предстали десятки старинных ружей и пистолетов. Далее пошли сабли, кинжалы, прочее холодное оружие, затем - домашняя утварь. И так во всех имевшихся 48 ящиках. Раритеты оказались в прекрасном состоянии. Каждое ружье было оригинально украшено тончайшим восточным орнаментом, инкрустацией, резьбой, серебром и перламутром. В ящиках находилось 443 ружья. Кроме того, были обнаружены и 134 пистолета. В некоторых из них даже имелся кремень. В ящиках оказалось и шестнадцать сабель, палашей, тесаков, кинжалов. Некоторые из них, по мнению экспертов-искусствоведов таможни, могли быть изготовлены в XVII - XVIII вв. Богато украшенными были не только рукояти и эфесы, но и сами клинки. Они были покрыты причудливыми узорами и арабской вязью. Не менее прекрасна была и старинная металлическая посуда. Кувшины, вазы, чаши были самых разных форм и объемов, но все богато украшенные, многие были выполнены из чистого серебра. Всего их насчитали 168 единиц. Кроме того, были обнаружены 182 тщательно упакованных самовара, изготовленных, главным обра-

${ }^{15}$ Брестская таможня. Доверено страной, ред.: А.М. Суворов, Брест 2014, c. 81 . 
зом, в российской Туле в XIX в. На некоторых из них были выбиты изображения медалей, присужденные этим изделиях на различных выставках. На многих образцах посуды сохранились мастичные печати с арабскими надписями, что указывало на их недавнюю принадлежность к музейным коллекциям.

Во втором контейнере оказалось 943 предмета. Их количество и подбор позволяли сделать вывод, что отправители груза хорошо разбирались в антиквариате. Примерная суммарная стоимость задержанных культурных ценностей исчислялась сотнями тысяч долларов.

Вскоре Брестская таможня направила рапорт своему руководству в Москву в Министерство внешней торговли. Но там, несмотря на существование в Бресте при областном краеведческом музее хорошо известной и популярной выставки спасенных художественных ценностей, было принято политическое решение немедленно вернуть их в Афганистан. К сожалению, этот широкий жест советского руководства в конечном итоге афганской культуре пользы не принес. По некоторым данным, раритеты попали в Европу уже кружным путем и позднее были проданы на аукционах в Лондоне.

Во второй половине 1980-х гг. количество попыток контрабандного перемещения товаров постоянно росло. Так, по сравнению с 1987 г., число задержаний предметов старины в целом по таможенной системе СССР увеличилось в 2,5 раза ${ }^{16}$. По некоторым данным, в 1988 г. в целом по СССР таможенники пресекли вывоз около 20 тысяч предметов искусства. Этот год, по единодушному мнению, экспертов, положил начало массовому вывозу за границу историко-культурного достояния народов Советского Союза. В СССР начинался экономический кризис, его следствием стало быстрое снижение жизненного уровня населения, и некоторые граждане

${ }^{16}$ Кисловский Ю.Г., История таможенного дела и таможенной политики России, ред.: А.Е. Жерихова, Москва 2004, с. 353. 
вынуждены были продавать предметы старины из своих семейных реликвий, частных коллекций. В то же время за рубежом уже давно проявляли повышенный интерес не только к старому дореволюционному искусству периода Российской империи, но и к работам советских мастеров.

Вывозом подобных культурных ценностей, в условиях отсутствия надлежащей правовой базы внешнеэкономической деятельности, в конце 1980-х гг. стали заниматься иностранцы, имевшие родственников в советских республиках, лица, ранее многократно посещавшие страны Восточной и Центральной Европы и хорошо ориентировавшиеся в обстановке и конъюнктуре рынка антиквариата и в целом искусства. Покупателями были и многочисленные иностранные «туристы»-коммерсанты. Европейские антикварные магазины и мелкие лавочки получили мощный источник поступления товаров и доходов. К примеру, в конце 1987 г. старший инспектор Брестской таможни из ручной клади гражданина одной из африканских стран, на тот момент студента советского высшего учебного заведения, выезжавшего в Западный Берлин, изъял 23 иконы и 100 кг черной икры. «Турист» рассказал, что весь груз он получил в московской гостинице и оплатил... партией женских платков с люрексом, нелегально ввезенных в $\mathrm{CCCP}^{17}$.

Пытаясь противостоять «океанской волне» контрабанды искусства 23 марта 1987 г. министр культуры СССР утвердил инструкцию «О порядке контроля за вывозом из СССР культурных ценностей». Так, не подлежали вывозу и пересылке из СССР предметы и коллекции, представляющие значительную историческую, научную, художественную или иную культурную ценность, как сохранившиеся целиком в своем первоначальном виде или фрагментарном состоянии. В число этих культурных ценностей вошли:

${ }^{17}$ На страже культурного наследия: Таможенная служба Беларуси в борьбе с контрабандой культурных цеенностей, ред.: А.Ф. Шпилевский, Минск 2007, c. 31 . 
архитектурные фрагменты, скульптура, живопись, графика всех стран и народов до 1945 г.; иконы и предметы религиозных культов; уникальные предметы всех эпох, изготовленные из золота, платины, натуральных драгоценных камней, серебра; отечественные и зарубежные монеты и коллекции монет, бумажные денежные знаки до 1960 г. включительно; отечественные и зарубежные ордена и нагрудные знаки, наградные и памятные медали; все виды холодного и огнестрельного оружия отечественного и зарубежного производства до 1945 г.; художественная мебель отечественного и зарубежного производства, изготовленная до 1945 г.; старинные и современные музыкальные инструменты; книги, изобразительные издания, картографические и нотные издания на русском языке, вышедшие по 1925 г.; иностранные книги, изобразительные издания, картографические и нотные издания, книги кирилловской и глаголической печати, вышедшие по 1800 г.; редкие почтовые марки и многое другое.

Разрешение на вывоз подобных предметов выдавалось особыми экспертами. Выдача разрешений производилась в специально уполномоченных органах и учреждениях культуры в 11 городах Советского Союза. В БССР этим органом было Управление культуры Минского городского исполнительного комитета. Кроме того, в 17 пунктах таможенного контроля, в т.ч. Бресте и Гродно работу по досмотру культурных ценностей, ввозимых в СССР и вывозимых за границу, наряду с таможенными учреждениями вели штатные группы искусствоведов-контролеров.

На искусствоведов-контролеров возлагалось проведение работы по досмотру культурных ценностей, ввозимых в СССР и вывозимых за границу; проведение регистрации культурных ценностей, временно ввозимых в СССР, а также контроль за их вывозом в соответствии с установленным порядком; проведение экспертизы и оценки задержанных таможенными учреждениями культурных ценностей с привлечением в необходимых случаях квалифицированных специалистов других организаций; ведение учета 
конфискованных в установленном порядке таможенными учреждениями культурных ценностей, а также выработка рекомендаций о передаче их в состав Государственного музейного фонда СССР. Именно искусствоведы-контролеры и сотрудники таможен стали прочным заслоном набиравшей размах контрабанде, противостоять которой было все труднее и труднее.

Так, в сентябре 1989 г. при досмотре багажа у гражданина Г., выезжавшего на постоянное местожительство в Израиль, сотрудники Брестской таможни обнаружили 17 старинных икон, гобелен фламандской работы XVIII в. и 30 мелких предметов старины и искусства, сокрытых от таможенного контроля. Позднее контрабандист был приговорен к шести годам лишения свободы ${ }^{18}$. В течение упомянутого 1989 г. гродненские таможенники 14 раз пресекали попытки незаконного вывоза предметов старины и искусства за границу. Среди них: иконы XVIII-XIX вв. - 64 шт., складни и их фрагменты XVIII-XIX вв. - 8 шт., кресты XVIII-XIX вв. - 4 шт., три декоративных панно XVI-XIX вв., две книги начала XIX в. Это отметим был обычный рядовой год для таможни конца 1980-х гг.

5 июля 1990 г. сотрудник специальной досмотровой группы Гродненской таможни досматривал пассажирский поезд Ленинград-Варшава-Берлин. Проведя досмотр большей части одного из вагонов поезда, он зашел в купе, в котором за границу следовало 3 пассажира. Осмотрев купе, старший инспектор установил, что люк межпотолочного пространства кем-то вскрывался. Отвинтив шурупы и открыв ключом люк, сотрудник таможни обнаружил в пустотелом пространстве над окном 13 полиэтиленовых пакетов, обернутых изоляционной лентой. Когда были вскрыты эти пакеты, на столе оказалось множество золотых изделий (около 1000 единиц), огромная сумма в валюте различных стран мира, а также орден Ленина и Золотая Звезда Героя Советского Союза. Редкая на тот момент попытка незаконного вывоза медали Золотая Звезда

${ }^{18}$ Там же, с. 33. 
Героя Советского Союза для многих стала шоком и получила тогда большой общественный резонанс.

7 ноября 1990 г. служащими той же таможни у гражданина Гвинеи, являвшегося сотрудником ЮНЕСКО, выезжавшего из СССР пассажирским поездом Москва - Варшава после пребывания по служебным делам, было задержано 79 предметов религиозного культа, представлявших историко-культурную ценность. Предметы религиозного культа находились в трех чемоданах, принадлежавших дипломату ${ }^{19}$. В том же году произошло интересное задержание и в Бресте. От вывоза за рубеж была спасена редкая икона «Святая Евфросиния Полоцкая». Святая Ефросинья Полоцкая издавна является небесной покровительницей Беларуси, поэтому спасение этой иконы имело, несомненно, и глубоко символичный характер.

В последний год существования СССР борьба с контрабандистами еще более усилилась. Только гродненские таможенники за 1991 г. произвели 51 задержание историко-культурных ценностей.

Системная деятельность таможенных служащих по спасению культурных и исторических ценностей от незаконного вывоза за рубеж давала свои плоды. Одним из ярких ее примеров стала выставка «Сокровища, возвращенные народу», развернутая в июне-июле 1988 г. в Минске в помещении Дворца искусств. Представленные на выставке картины - «Спящая Венера», «Мария Магдалена», «Мифологическая сцена», «Портрет девушки», «Батальная сцена» неизвестных авторов XIX в., «Портрет девочки» (1900) А. Терещенко, «Портрет женщины с ребенком» (1911) Ф. Шенберга, «Горное озеро» (1893) Р. Крауса, «Ландскнехт» (XIX в.) за возможным авторством Э. Менсанье, значительное количество произведений белорусского иконописания (XVII-XIX вв.), церковные предметы, антикварные вещи, в большинстве своем датированные XIX

${ }^{19}$ Пять веков Гродненской таможенной службы, ред.: В.Ю Саяпин, Гродно 2003, c. 287. 
- началом XX вв., и многочисленные иные произведения искусства $^{20}$. Они, несомненно, имевшие большую историческую и художественную ценность, попав за границу, могли бы пополнить частные коллекции деятелей от искусства, если бы на их пути не оказались таможенники. Еще более монументальным результатом и одновременно презентацией деятельности таможенной службы по спасению культурных и исторических ценностей стало создание в 1989 г. в Бресте уникального музея «Спасенные художественные ценности». В советской прессе его часто именовали «Брестский Лувр» ${ }^{21}$.

Опыт противостояния контрабанде историко-культурных ценностей, накопленный таможенниками Беларуси в 1950-х - 1980-х гг, остается ценным и актуальным и сегодня. Его всестороннее изучение и применение востребовано современными стражами рубежей государства для успешного противодействия преступникам от культуры. Будни границы постоянно демонстрируют нам все новые свидетельства изощренных попыток контрабанды культурных ценностей. Так, несколько ярких примеров из этой области за прошедшие 2017-2018 гг. ${ }^{22}$

2017 г. Сотрудниками таможни «Минск-2» при проведении таможенного контроля в отношении международных почтовых отправлений из Германии и Швейцарии, поступившего в адрес жителя г. Минска, были выявлены не заявленные в сопроводительных документах исторические раритеты: 5 медных денариев I-II века до нашей эры. Всего в 2017 г. таможней «Минск-2» было пресечено 32 попытки незаконного перемещения предметов, относенных к категории культурных ценностей.

${ }^{20}$ На страже культурного наследия: Таможенная служба Беларуси в борьбе с контрабандой культурных ценностей, ред.: А.Ф. Шпилевский, Минск 2007, c. 39.

${ }^{21}$ Там же, с. 40.

22 По материалам пресс-службы Государственного таможенного комитета Республики Беларусь. 
Брестская таможня передала известному музею «Спасенные художественные ценности» 15 историко-культурных ценностей, которые пытались незаконно переместить через таможенную границу. По решению суда они были конфискованы у граждан, нарушивших таможенное законодательство. В числе раритетов - икона XIX в. «Двунадесятые праздники», которую хотел нелегально вывезти из страны житель Украины, 13 орденов и медалей были обнаружены у гражданина России, а также редкая бразильская монета 1871 г., которую перемещал без декларирования водитель из Казахстана. Только за последние два года брестскими таможенниками было изъято свыше 460 историко-культурных ценностей, многие из которых впоследствии пополнили «таможенные» коллекции музеев Беларуси.

Гродненские таможенники нашли в багаже пассажира, который направлялся в Германию более 20 незадекларированных культурных ценностей. Среди раритетов: изготовленные в Швеции в первой половине XIX в. столовые приборы, кубки и блюда начала XX в., финская монета 1917 г., польские юбилейные знаки и медали середины XX в. Наиболее ценной была воинская награда Знак окончивших Первые Советские Петроградские кавалерийские курсы (1920 г.).

2018 г. сотрудники Гродненской таможни в тайнике автомобиля возвращавшегося из Испании гражданина Армении, извлекли почти 1000 монет и более 1700 банкнот различных государств и различных номиналов, карманные и наручные часы, медальоны и др. Наиболее ценны среди них были старинные монеты времен Римской империи и Византии, а также арабские дирхемы XIII в., карманные французские часы конца XIX в.

Сотрудники Гомельской таможни пресекли попытку незаконного перемещения историко-культурных ценностей, имевшихся у гражданина России, следовавшего из Украины на автомобиле. В салоне и багажнике его легкового автомобиля таможенники обнаружили различные раритеты, среди которых - монеты, женские украшения, небольшие литые иконы. Всего более 560 монет 
и около 30 изделий. После проведения экспертизы было установлено, что часть предметов имеют археологический характер и относятся к периоду Черняховской культуры III - IV в. н.э., а монеты из серебра отчеканены в России в XVI - XVIII вв.

Очевидно, что проблема незаконного перемещения артефактов становиться все более серьезной. Ныне объем денежных средств от нелегальной продажи историко-культурных ценностей находится на третьем место после прибылей от незаконной торговли наркотиками и оружием. Так, по оценке Еврокомиссии, контрабанда культурных ценностей в мировом масштабе в настоящее время оценивается в размере от 1 до 5 миллиардов евро в год. Но в последние десятилетия эта глобальная проблема современности стала приобретать новый, совсем зловещий оттенок. По мнению экспертов, контрабанда артефактов не просто обедняет культурное наследие человечества. Доходы, получаемые от незаконных продаж историко-культурных ценностей из стран, прежде всего Азии и Африки, затронутых вооруженными конфликтами, все чаще идут на финансирование террористов, пытающихся действовать и в Европе. В этой связи, вызывает большую озабоченность тот факт, что, по экспертным оценкам, только в 2015 г. через руки террористической группировки «Исламское государство», прошли около 100 тысяч археологических артефактов. Поэтому в настоящее время на территории ЕС введен запрет на торговлю культурными ценностями из Ирака и Сирии, где боевые действия ведутся и в местностях, богатых на историко-культурные ценности мирового значения, чтобы минимизировать финансовые источники возможности террористов ${ }^{23}$.

В итоге, исходя из этого нового взгляда на контрабанду артефактов, в ноябре 2018 г. был одобрен предложенный Еврокомиссией проект регламента ЕС по предотвращению импорта и хране-

${ }^{23}$ Евросоюз ужесточил борьбу с контрабандой культурных ценностей https:// ria.ru/20181107/1532285760.html . - Дата доступа 15.01.2019. 
ния на территории сообщества культурных ценностей, незаконно вывезенных из стран, не входящих в ЕС. Кроме того, считается, что данный регламент дополнит существующую правовую базу ЕС по торговле культурными ценностями, регулировавшую экспорт культурных ценностей и возвращение культурных объектов, незаконно вывезенных с территории страны ЕС. Регламент будет распространятся на культурные ценности, созданные или найденные за пределами ЕС, которые старше 250 лет и стоимость которых не менее 10 тысяч евро. Данный регламент вступит в силу в январе 2019 г.

Таким образом, анализ деятельности сотрудников белорусских таможен в период с 1944 по 1991 гг. демонстрирует активную и успешную работу по противодействию незаконному вывозу историко-культурных ценностей. Эта, несомненно, благородная деятельность, предотвратила контрабанду тысяч уникальных раритетов национального и мирового значения, сформировавших с течением времени в музеях Беларуси особенные «таможенные» коллекции. Опыт работы прошлых поколений таможенников важен и сегодня для решения очередных задач борьбы с транснациональной преступностью, поиска адекватных ответов на новые вызовы человечеству.

\section{Библиография}

Albom-katalog,,Slutskiyepoyasa”,http://nasledie-sluck.by/ru/sluchina/114/4919/. [data dostupa: 15.12.2018] [Альбом-каталог «Слуцкие пояса». http://nasledie-sluck.by/ru/sluchina/114/4919/. Дата доступа 15.12.2018].

Brestskaya tamozhnya, Dovereno stranoy, red.: A.M. Suvorov, Brest 2014 [Брестская таможня. Доверено страной, ред.: А.М. Суворов, Брест 2014]. Gosudarstvennaya tamozhennaya sluzhba Respubliki Belarus. Istoriya i sovremennost, red.: A. F. Shpilevskiy, Minsk 2006 [Государственная таможенная служба Республики Беларусь. История и современность, ред.: А.Ф. Шпилевский, Минск 2006].

Istoriya pogranichnoy sluzhby Belarusi, red.: V.V. Davydik, Minsk 2011 [История пограничной службы Беларуси / В.В. Давыдик [и др.], ред.: В.Г. Моисеенко, Минск 2011]. 
Kislovskiy Y. G., Istoriya tamozhennogo dela i tamozhennoy polityki Rossii, red.: A. Je., Zherikhov, Moskva 2004 [Кисловский Ю.Г., История таможенного дела и таможенной политики России, ред.: А.Е. Жерихова, Москва 2004].

Na strazhe granits Otechestva. Istoriya pogranichnoy sluzhby. Kratkiy ocherk, Moskva 1998 [На страже грании Отечества. История пограничной службы. Краткий очерк, Москва 1998].

$\mathrm{Na}$ strazhe kulturonogo naslediya: Tamozhennaya sluzhba Belarus v borbe s kontrobandoy kulturnykh tsennostey, red.: A.F. Shpilevskiy, Minsk 2007 [Ha страже культурного наследия: Таможенная служба Беларуси в борьбе с контрабандой культурных иенностей, ред.: А.Ф. Шпилевский, Минск 2007].

Nukolayev A., Christoprodavcy, „Smena” 1989, № 21, s. 7-9 [Николаев А. Христопродавцы // Смена. - 1989. - № 21. - С. 7-9].

Olimpiada naczinajetsia... s tamożni, http://museum.customs.ru/index. php? view $=$ article \& catid $=7 \% 3$ Apublications \&id=49\%3 A2014-01-20-06-32-06\&format=pdf\&option=com_content\&Itemid=11 (data dostupa: 15 01.2019) [Олимпиада начинается ... с таможни http://museum.customs.ru/ index.php?view $=$ article \&catid=7\%3Apublications \&id=49\%3A2014-01-20-06-32-06\&format=pdf\&option=com_content\&Itemid=11. Дата доступа 15 $01.2019]$.

Ostroga V.A., Kartinki s vystavki, „Tamozhnya i VED” 2004, nr 4, s. 63-64 [Острога В.А., Картинки с выставки, “Таможня и ВЭД” 2004, № 4, с. 63-64].

Piat'vekov Grodnenskoy tamozhennoy sluzhby, red.: V. J. Sayapin, Grodno 2003 [Пять веков Гродненской таможенной службы, ред.: В.Ю Саяпин, Гродно 2003].

Sayapin V.J., Tamozhennaya sluzhba. Ch. 2. Borba s kontrobandoy, Grodno 2005 [Саяпин В.Ю., Таможенная служба. В 2 кн. Кн. 2. Борьба с контрабандой, Гродно 2005].

Yevrosoyuz uzhestochil borbu s kontrobandoy kulturnykh tsennostey, https:// ria.ru/20181107/1532285760.html (data dostupa: 15.01.2019) [Евросоюз ужесточил борьбу с контрабандой культурных ценностей https://ria. ru/20181107/1532285760.html . - Дата доступа 15.01.2019]. 


\section{Belarusian customs officers in the fight with smuggling of historical and cultural values (1944-1991).}

The article analyzes the activities of customs officers who were on the territory of Soviet Belarus in 1944 - 1991, aimed at preventing the illegal movement of historical and cultural values across the customs border. In the chronological sequence, against the background of the development of special international and Soviet legislation, the study examines the transformation of methods and capabilities of customs officers in the field of protection of cultural heritage. Special attention is paid to counteraction to illegal transportation across the border of religious objects, mainly icons. It is indicated that in the early 1970s, the icons detained on the border, previously largely destroyed, began to be massively transferred to the funds of various museums in Belarus, and a separate unique Museum was created for this purpose in Brest. The most vivid and characteristic ways and places of hiding historical and cultural artifacts by smugglers are described. It is concluded that the Belarusian customs officers in the period under review actively and successfully opposed the illegal export of historical and cultural values through the customs border.

Keyword: Belarus, cultural and historical values, religious objects, icons, legislation, customs, customs officer, smuggling, smuggler, hiding place. 